\title{
Bashar al-Assad har skabt et nyt monster
}

\section{Af Lasse Ellegaard}

Da den i udgangspunktet fredelige syriske revolte brød ud i marts 2011 besluttede regimet i Damaskus at trække det sekteriske kort med den hensigt at tvinge Syriens politiske opposition og dens støtter i Vesten og Golfen til at vælge mellem pest og kolera - Baath-diktaturet eller Islamisk Stat.

Da jeg tidligt den 9. september åbnede pc'en for bl.a. at skrive denne artikel, meddelte det globale nyhedstapet, at jihadchefen Hassan Aboud var dræbt i en bunker i Idlib-provinsen, hvor han sad i møde med sine kommandanter i Ahrar al-Sham (Levantens Frie Mænd), en magtfuld islamistisk oprørsmilits og ledende i paraplyorganisationen Islamisk Front.

Hassan Aboud blev således endnu en martyr i den tofrontskrig, hvor oprørsstyrker i Syrien kæmper mod såvel Bashar alAssads regime som Islamisk Stat, IS - tidligere kendt som ISIL, Islamisk Stat i Irak og Levanten. IS står sandsynligvis bag selvmordsbomben, der dræbte Hassan Aboud tillige med 42 andre ofre fra Ahrar alShams generalstab.

\section{Ny 'koalition af villige'}

Et miks af militær finesse, religiøs fanatisme, ekstraordinær brutalitet og politisk tæft har siden sommeren 2013 gjort IS til den centrale aktør i den syriske borgerkrig. Den ekstremistiske jihad-organisation kontrollerer hovedparten af det nordlige og østlige Syrien, herunder oliefelterne nær Deir es-Zour, og via alliancer med irakiske sunniklaner, eks-officerer fra Saddam Husseins hær og støtter i det nu forbudte Baath-parti kontrollerer IS Anbar-provinsen mod vest og Mosul med tilstødende provinser ned mod Bagdad.

Deres 'blitzkrieg' i juni, der på under en uge erobrede et område større end Frankrig, forskrækkede vestlige og arabiske regeringer i en sådan grad, at en 'koalition af villige' nu er stykket sammen på initiativ af USA med arabiske og europæiske deltagere og med baser i Saudi-Arabien som under den første Golf-krig i 1991. Men i modsætning til 1991 (og 2003) er koalitionen i skrivende stund uden en fast defineret op-

Lasse Ellegaard, korrespondent i Tyrkiet, Israel/Palæstina, Storbritannien og Libanon i perioden 1995-2014. Er i dag medarbejder på Information med Mellemøsten som speciale. Har skrevet bøgerne Med Gud i hælene [2007) og Det forrykte forår [2012]. 
Der er således ingen garanti for, at mere avancerede våben til det 'moderate' fantom nytter noget, hvorimod der nu som før er høj risiko for, at de falder i forkerte hænder.

Så næste logiske skridt, hvis IS skal elimineres som regional aktør, vil være vestlig militær intervention, formentlig i NATOregi og på 'invitation' fra den nydannede irakiske regering.

\section{Hvad gør Obama og NATO?}

En sådan udgang vil formelt friholde $\mathrm{Ba}$ rack Obama fra besværet med at forklare en de facto genbesættelse af Irak mindre end tre år efter, at den sidste amerikanske kampsoldat krydsede grænsen til Kuwait. Og jo, jeg er helt klar over, at ledende politikere og deres spindoktorer slår syv kors for sig, når der stilles spørgsmål til betimeligheden af endnu en vestlig intervention i den muslimske region. Og det synes evident, at Barack Obama vil gøre hvad han kan for at undgå, at det sker - men hvad kan USA (og Vesten) stille op, når IS ikke vil gå væk?

Obama påpegede i sin tale den 10 . september, at jihadisterne ganske vist ikke lige nu udgør en direkte terrortrussel mod USA, men at truslen er i horisonten, hvis de ikke stoppes nu.

Så det er en nærliggende tanke, at beslutningen på NATO-topmødet i Wales den 4.-5. september om etablering af en udrykningsstyrke (Readiness Action Plan), der kan 'reagere på risici og trusler fra vort sydlige nabolag, Mellemøsten og Nordafrika', er skræddersyet til indsættelse mod IS i Irak - og på sigt i Syrien. Denne nye styrke er samtidig en erkendelse af, at truslen fra den al Qaeda-designede radikale islamisme er nærmere end nogensinde på alliancens kerneområde.

Jihadisterne i IS kan i dag se ind i NATO-landet Tyrkiet uden brug af kikkert hvad Tyrkiet kan takke sig selv for efter at have åbnet grænsen og tilladt importen af hellige krigere til det nordlige Syrien.
At det er kommet så vidt, skyldes en lang række faktorer, som ligger uden for denne artikels rækkevidde. Men en afkodning af IS-angrebet på Ahrar al-Sham og Hassan Aboud kaster lys på en hovedfaktor, måske den vigtigste, nemlig det syriske regimes dygtigt udtænkte strategi for overlevelse. Det lykkedes faktisk Bashar al-Assad at skabe et monster, der er værre end ham selv.

Den syriske revolutions forløb - fra de første folkelige og fredelige demonstrationer i februar-marts 2011 til den dagsaktuelle tragedie, der, når dette læses, har kostet i hvert fald 200.000 menneskeliv og drevet andre otte-ni millioner på flugt - fører direkte tilbage til det syriske regimes amnesti til islamiske politiske fanger, heraf adskillige jihadister, i april 2011.

Hassan Aboud var den gang blandt de løsladte ligesom to andre, Zahran Allouch, der gik ud og dannede Suqour alSham (Levantens Falke) og Ahmad Aisa al-Shaik, der blev leder af Jaysh al-Islam (Islams Hær). Fælles for dem i sommeren 2013 var deres placering på Top-3-listen over oprørets mest magtfulde militsledere. Det andet fælles træk var parolen om Syriens fremtid som islamisk stat og en kategorisk afvisning af at anerkende den vestligt og golf-arabisk støttede eksilopposition, Syriens Nationale Koalition for Revolutions- og Oppositions-styrker, SNC.

De var også fælles om dannelsen af Islamisk Front og alliancens kortvarige fordrivelse af IS fra Raqqa, den eneste syriske provinshovedstad, der er på oprørernes hænder. Forgæves, skulle det vise sig IS trak sig tilbage, omgrupperede og tog så Raqqa tilbage som base for den senere erobring af Mosul i juni 2014, og er i dag regionens dominerende jihad-styrke med annonceringen af det såkaldte 'kalifat', der kom fuldkommen bag på de vestlige og arabiske regeringer. Men næppe på styret i Damaskus.

For den væsentlige medårsag til IS’ mi- 
litære succes var den de facto immunitet, de fik tildelt af Bashar al-Assad helt frem til sommeren 2014. Det syriske regime undlod konsekvent at angribe IS-positioner i det nordlige Syrien - eksempelvis stod deres hovedkvarter i Raqqa urørt - men koncentrerede bombardementer med artilleri og luftvåben mod de mere moderate militser, Islamisk Front og Jabhat al-Nusra (Sejrrig Front) og resterne af den sekulære FSA (Frie Syriske Hær), eksil-oppositionens militære arm.

\section{Bashars forkerte valg}

Ved at spille det sekteriske kort fra begyndelsen af revolten drejede Bashar al-Assad den væk fra udgangspunktet, der var politisk-nationalistisk og afstemt med syrernes grundlæggende tolerante adfærd i deres brogede samfunds kludetæppe af etniske og religiøse grupperinger. Og som den socialistisk-sekulære hjernevask, der fulgte med Baath-partiets militærkup i 1963, faktisk stimulerede. Baathisternes alawitledelse indså, at borgfred med landets to tredjedele sunnitter - og politisk alliance med de kristne, drusiske, armenske og turkmenske minoriteter - var forudsætningen for stabilitet.

Den holdt frem til nogle år efter Hafez al-Assads ublodige officerskup i 1970, der fjernede den sunnitiske kransekage-præsident, Nour al-Atassi og al-Assads alawitrivaler i hæren. Men i perioden 1979-82 fremkaldte fejlslagne økonomiske reformer ny utilfredshed, der blev afsæt for en opstand anført af Det Muslimske Broderskab, som var imod Baath-partiets sekularisme. Opstanden kulminerede i Hama med en massakre - nogle kilder anslår at mellem 20.000 og 30.000 blev dræbt - men 'Hamareglen', som massakren siden blev kaldt, tilvejebragte ubrudt politisk stabilitet og hen ad vejen økonomisk vækst frem til 2011.

Det er generelt accepteret latin i Syriendebatten at sætte lighedstegn mellem Hafez al-Assads Hama-massakre og sønnen
Bashar al-Assads krigsforbrydelser mod sine landsmænd, men ligningen holder ikke vand. Som den tyske Syrien-forsker Carsten Wieland har påpeget, stod $\mathrm{Hafez}$ med ryggen mod muren over for en væbnet opstand, der i Hama blev iværksat af officerer fra det syriske luftvåben med tilknytning til Det Muslimske Broderskab. Hafez havde ikke noget valg, hvis han ville overleve politisk, og reagerede altså på en konkret trussel udefra. Bashar al-Assad fremkaldte bevidst den konkrete trussel mod sit regime, da han valgte 'sikkerhedsløsningen' frem for en politisk løsning på bølgen af de grundlæggende fredelige og etnisk-religiøst brede demonstrationer, der skyllede hen over Syrien fra midten af marts 2011 og frem til sensommeren.

Han valgte indlysende forkert, men kunne have truffet det rigtige valg: at gøre sig selv til løsningen i stedet for problemet. I de første uger - og også efter shabiha'er og sikkerhedsstyrker havde leveret lig i gaderne - undlod demonstranterne bevidst at forlange 'Nummer 1's - præsidentens - hoved på et fad (shabiha betyder 'genfærd' og var oprindeligt alawitiske smuglere og voldsmænd i kystområdets bjerge, der blev lønnet og beskyttet af medlemmer af Assadfamilien). Demonstranterne krævede først og sidst 'værdighed' - deres paroler handlede ikke om demokrati og ytringsfrihed, men mere om leden ved arrogant skrankepave-korruption, den automatiserede nepotisme og den sikkerhedsparanoia, der er enhver totalitær stats hjertekammer.

Eksempelvis godkendte sikkerhedstjenesterne, mukhabarat, alle ejendomshandler, hvilket aldrig skete uden vederlag, ligesom de tog sig betalt for den obligatoriske udstedelse af rejsetilladelser. I Dera'a, hvor det egentlige oprør begyndte den 15. marts 2011 efter nogle forkølede tilløb i Damaskus, blev en politistation og det lokale $\mathrm{Ba}$ ath-partikontor brændt i kampens hede, men stadig uden at Bashar al-Assads navn blev påkaldt i protesterne. Demonstranter- 
ne havde et håb om, at den faktisk ret populære unge præsident - han var 45 - ville lytte og reagere.

Og måske overvejede han at lytte og reagere. I hvert fald har hans daværende vicepremierminister, Abdullah Dardari, fortalt mig og min kollega Ole Damkjær, da vi interviewede ham i Beirut i 2013, at han talte flere timer i telefon med Bashar dagen før fredag den 18. marts 2011, der var annonceret som 'vredens dag' på en syrisk facebook-portal, og rådede ham til at stille sig $\mathrm{i}$ spidsen for protesterne ved at dekretere demokratiske reformer.

"Men", tilføjede Dardari. "jeg sluttede samtalen med at sige, at jeg godt vidste han ville lytte mere til familien og sikkerhedscheferne end til mig."

\section{Fra politisk til sekterisk konflikt}

Nedskydning af demonstranter, der søgte tilflugt i moskéerne - det eneste sted i Syrien, hvor folk kunne mødes i større antal - men især regimets indsættelse af shabiha'erne betød, at konflikten hurtigt udviklede sig sekterisk frem for politisk Typisk fulgte shabihaerne regimets to elitedivisioner ledet af alawit-officerer og befalingsmænd, der blev indsat mod demonstranter. Når tropperne havde trukket sig tilbage, gik shabihaerne i gang med plynd- ringer, voldtægter og i ekstreme tilfælde mord på sunnitiske civile.

Jeg var selv vidne til, hvordan en flok skrækslagne kvinder fra en syrisk landsby, mange af dem med børn, i revoltens første måned ankom til grænseovergangen Wadi Khaled i det nordlige Libanon, efter at libanesiske sunni-aktivister havde samlet dem op i busser på vejene uden for landsbyen.

Og som revolten foldede sig ud i de velstående landbrugsområder omkring sunnibyerne Homs og Hama, organiserede bønderne sig i lokale landsbyværn, de købte våben på det sorte marked i bl.a. Libanon, og gradvist omdannedes de til egentlige paramilitære militser. Som en syrisk bekendt i Beirut, Ali Atassi - i øvrigt søn af den i 1970 fængslede præsident - svarede, da jeg spurgte ham, om det nu også var politisk klogt af de syriske sunnitter at gribe til våben: "Næh, men du kan ikke fortænke folk $i$ at forsvare koner og børn."

Den samme logik kan have foresvævet Bashar al-Assad, der også har kone og børn, og som ifølge adskillige og troværdige kilder aldrig fattede sin befolknings krav (og håb) om inklusion i hans sekterisk dominerede styre, men udelukkende så Hama-scenariet gentage sig for sit indre blik. Og reagerede derefter. 